\title{
A horizontally acquired group II intron in the chloroplast psbA gene of a psychrophilic Chlamydomonas: In vitro self-splicing and genetic evidence for maturase activity
}

\author{
OBED W. ODOM, DAVID L. SHENKENBERG, JOSHUA A. GARCIA, and DAVID L. HERRIN \\ Section of Molecular Cell and Developmental Biology and Institute for Cellular and Molecular Biology, School of Biological Sciences, \\ University of Texas at Austin, Austin, Texas 78712, USA
}

\begin{abstract}
The majority of known group II introns are from chloroplast genomes, yet the first self-splicing group II intron from a chloroplast gene was reported only recently, from the $p s b A$ gene of the euglenoid, Euglena myxocylindracea. Herein, we describe a large $(2.6-\mathrm{kb})$ group II intron from the $p s b A$ gene ( $p s b A 1)$ of a psychrophilic Chlamydomonas sp. from Antarctica that self-splices accurately in vitro. Remarkably, this intron, which also encodes an ORF with putative reverse transcriptase, maturase, and endonuclease domains, is in the same location, and is related to the E. myxocylindracea intron, as well as to group IIB2 introns from cyanobacteria. In vitro self-splicing of Chs.psbA1 occurred via a lariat, and required $\mathrm{Mg}^{2+}\left(>12 \mathrm{mM}^{2}\right.$ and NH${ }_{4}^{+} . \mathrm{Self}_{-}$ splicing was improved by deleting most of the ORF and by using pre-RNAs directly from transcription reactions, suggestive of a role for folding during transcription. Self-splicing of $C h s . p s b A 1$ pre-RNAs showed temperature optima of $\sim 44^{\circ} \mathrm{C}$, but with a broad shoulder on the low side of the peak; splicing was nearly absent at $50^{\circ} \mathrm{C}$, indicative of thermolability. Splicing of wild-type Chs.psbA1 also occurred in Escherichia coli, but not when the ORF was disrupted by mutations, providing genetic evidence that it has maturase activity. This work provides the first description of a ribozyme from a psychrophilic organism. It also appears to provide a second instance of interkingdom horizontal transfer of this group IIB2 intron (or a close relative) from cyanobacteria to chloroplasts.
\end{abstract}

Keywords: Chlamydomonas; chloroplast; group IIB2 intron; horizontal transfer; maturase; psbA gene; psychrophilic; self-splicing

\section{INTRODUCTION}

Ribozymes play key roles in gene expression likely in all cells; however, relatively little is known about how they have adapted to the wide range of niches that organisms occupy in the biosphere. Adaptation to temperature is one of the best studied aspects of biochemical adaptation (Hochachka and Somero 2002); however, only a few of these studies have been with ribozymes, and all involved thermophily (Brown et al. 1993; Fang et al. 2001; Nesbo and Doolittle 2003). Protein enzymes from psychrophilic organisms typically have lower temperature optimums, reduced thermostability, and are more efficient catalysts than mesophilic

Reprint requests to: David L. Herrin, Section of Molecular Cell and Developmental Biology and Institute for Cellular and Molecular Biology, School of Biological Sciences, University of Texas at Austin, 1 University Station A6700, Austin, TX 78712, USA; e-mail: herrin@mail.utexas.edu; fax: (512) 471-3843.

Article and publication are at http://www.rnajournal.org/cgi/doi/ 10.1261/rna.7140604. enzymes (Hochachka and Somero 2002). Greater flexibility is one mechanism that psychrophilic protein enzymes use to maintain function at low temperature. It is not known how ribozymes have adapted to function at low temperature, because classical ribozymes have not been characterized from psychrophilic organisms.

Group II introns are one of the major classes of large ribozymes, and are found in eukaryotic organelles, prokaryotes (for review, see Michel and Ferat 1995; Bonen and Vogel 2001), and archaea (Dai and Zimmerly 2003). They have conserved terminal sequences and secondary structure elements, and several subgroups have been defined. Some group II introns contain an ORF that has coevolved with the intron core (Fontaine et al. 1997; Toor et al. 2001), and for the few whose functions have been studied, they promote splicing (maturase) and mobility of the host intron (Lambowitz et al. 1999). Several group II introns from mitochondria and bacteria have been shown to self-splice in vitro in the absence of proteins (Michel and Ferat 1995; Bonen and Vogel 2001). Splicing occurs by a two-step 
mechanism, with the first step proceeding mainly via a lariat, but it can also occur by hydrolysis (Daniels et al. 1996; Podar et al. 1998; Vogel and Börner 2002). Although the majority of known group II introns are from chloroplast genes (Cannone et al. 2002), the first report of self-splicing by a chloroplast group II intron appeared just recently (Sheveleva and Hallick 2004). Also, chloroplast group II intron-encoded maturases, in particular matK, have been inferred (du Jardin et al. 1994; Liere and Link 1995; Vogel et al. 1997, 1999; Doetsch et al. 1998), but not directly demonstrated to promote splicing.

Species of Chlamydomonas are known from cold environments, where they are often referred to as snow or ice algae (Hoham and Duval 2001; Thomas and Dieckmann 2002). The chloroplast genomes of Chlamydomonas spp. (mostly mesophilic) are excellent sources of group I intron ribozymes (Herrin et al. 1998), but for unknown reasons, typical cis-spliced group II introns have not been reported. To identify a ribozyme from a psychrophilic organism, we searched chloroplast $p s b A$ and $23 S$ rRNA genes of snow/ice Chlamydomonas by PCR, expecting to find group I introns. Surprisingly, a cis-spliced group II intron (Csp.psbA1) containing a large ORF was present in the $p s b A$ gene of a Chlamydomonas from the depths of Lake Bonney, Antarctica, a permanently ice-covered lake (Neale and Priscu 1995). It has been possible to examine the splicing of this intron in vitro, and in vivo in Escherichia coli and in its normal host.

\section{RESULTS}

\section{The organism}

Chlamydomonas strain CCMP-1619 grew well at temperatures ranging from $4^{\circ} \mathrm{C}$ (the lowest temperature tried) to $15^{\circ} \mathrm{C}$, but did not grow at $20^{\circ} \mathrm{C}$, confirming that it is a psychrophilic organism. CCMP-1619 also did not grow when the cultures were shaken, consistent with adaptation to its highly nonturbulent environment (Neale and Priscu 1995). Several studies of a prominent Chlamydomonas from Lake Bonney referred to it as C. subcaudata (Morgan et al. 1998; Morgan-Kiss et al. 2002), which is an egg-shaped species with a protrusion of the posterior cell wall (Ettl 1976). Light microscopy of CCMP-1619 did not reveal any cells with that morphology; however, instead, the cells were highly spherical and a typical example is shown in Figure 1. The larger cells were $\sim 15 \mu \mathrm{m}$ in length, and most appeared to be highly vacuolated.

To determine the relationship between CCMP-1619, the species studied by Huner et al. (Morgan et al. 1998; Morgan-Kiss et al. 2002), and C. subcaudata, the chloroplast petA-petD region was amplified from CCMP-1619 and sequenced (accession no. AY332410). The petA (723 bp) and petD (37 bp) coding regions from CCMP-1619 are identical to those deposited by Huner et al. (accession no.

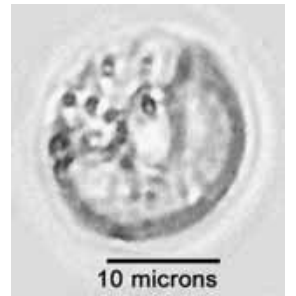

FIGURE 1. Light microscope image of Chlamydomonas sp. CCMP1619. The cells were grown in liquid medium at $4^{\circ} \mathrm{C}$, and the image was captured with a digital camera at a total magnification of $600 \times$. The scale bar is $10 \mu \mathrm{m}$.

AY039799), and the intergenic spacer differs by $<1 \%$ (eight out of 1065 residues). However, the petA coding region from authentic C. subcaudata is only $\sim 90 \%$ identical to CCMP-1619, and the intergenic spacer is only $\sim 40 \%$ identical (not shown). Thus, these results indicate that CCMP1619 is essentially the same species studied previously (Morgan et al. 1998; Morgan-Kiss et al. 2002), but it is not C. subcaudata. Analysis of nuclear rRNA ITS sequence, and other data, suggests that it is a strain of Chlamydomonas raudensis (T. Pocock, M.A. Lachance, T. Proeschold, S. Kim, and N. Huner, pers. comm.).

\section{The intron}

Amplification and sequencing of the $3^{\prime}$ half of the $p s b A$ gene from CCMP-1619 (accession no. AY325305) revealed the presence of one large $(2572 \mathrm{bp})$ group II intron that splits the $\mathrm{V}^{185}$ codon. Computer translation of the flanking exon sequences (284 bp) gave an amino acid sequence identical to Chlamydomonas reinhardtii psbA. BLAST searches using the exon DNA sequences produced the highest similarity scores with green algal $p s b A$ genes. The G-C content (38\%) and codon usage of the CCMP-1619 exon sequences are also similar to those of green algal chloroplast genes, which are quite different from nuclear genes in these organisms. These results indicate that the amplified $p s b A$ gene is from the chloroplast of CCMP-1619, which is where it is located in all other photosynthetic eukaryotes that have been examined.

The predicted secondary structure of this Chlamydomonas sp. (CCMP-1619) psbA intron, which we named Chs.psbA1 (Fig. 2), has the common group II domains I-VI and all of the tertiary interactions characteristic of group IIB2 (chloroplast-like class 2) introns (Michel et al. 1989; Toor et al. 2001). The intron is most similar in secondary structure to the recently described intron from the chloroplast psbA gene of Euglena myxocylindracea (Sheveleva and Hallick 2004) and to introns from the cyanobacteria Calothrix sp. (Cal.x1; Ferat and Michel 1993) and Nostoc sp. PCC 7120 (bp 45,420-48,000; Kaneko et al. 2001), which are not located in $p s b A$ genes. An idiosyncrasy of the Chs.psbA1 intron is an unusual insertion in domain ID (nt 275-310) 


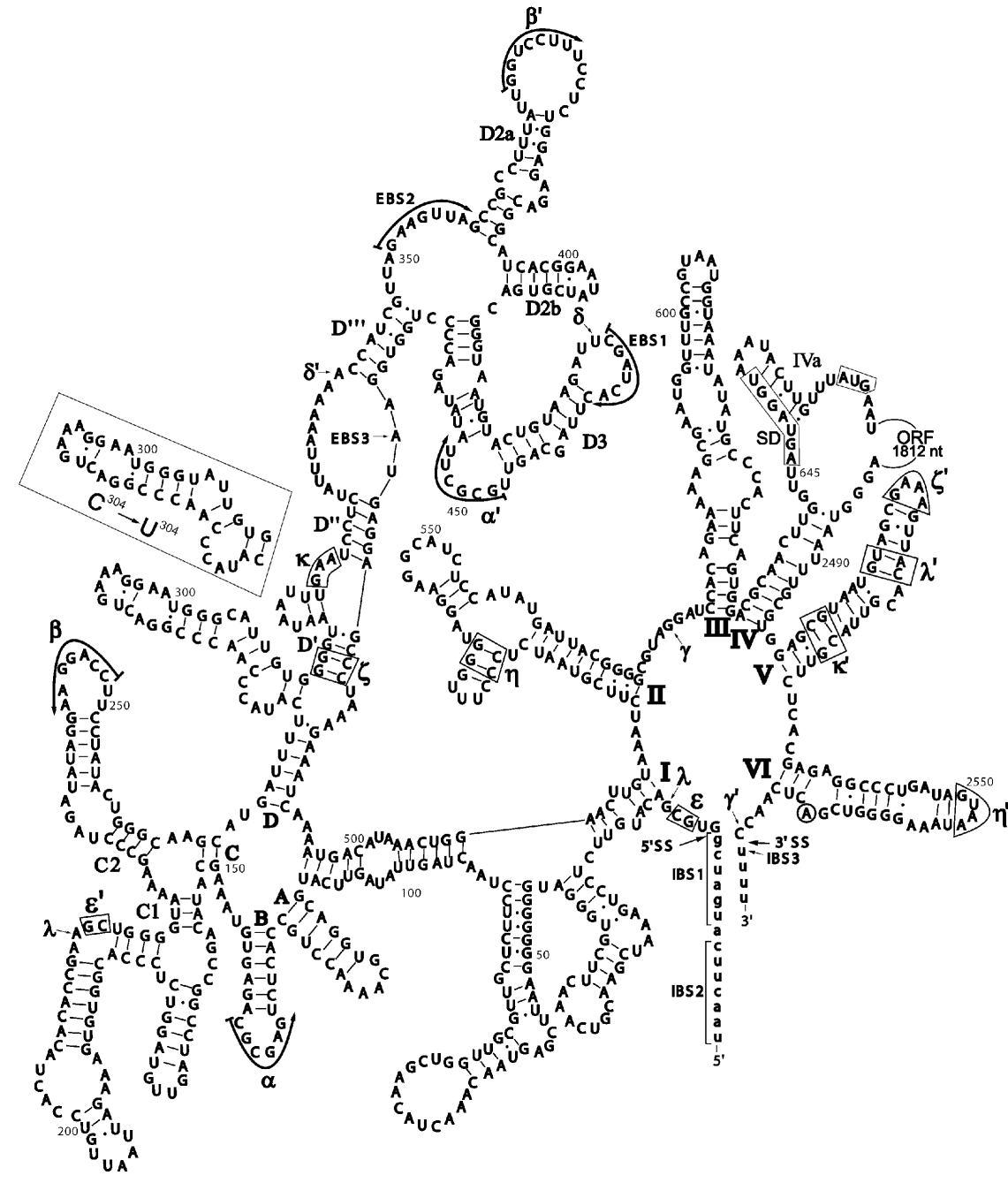

FIGURE 2. Proposed secondary structure of the 2572-bp Chs.psbA1 intron. Intron nucleotides are in uppercase and numbered from the $5^{\prime}$ end; exon nucleotides are in lowercase. $5^{\prime}$ SS and $3^{\prime}$ SS are the splice sites. The major domains are labeled with Roman numerals (I-VI) and subdomains of domain I as A, B, C (C1 and C2), and D (D", D'", D2a, D2b, D3). Tertiary interactions are labeled with Greek letters $\left(\alpha-\alpha^{\prime}\right.$, etc.). EBS and IBS refer to exon and intron binding sites, respectively. The Shine-Dalgarno (SD) sequence and start codon (AUG) of the ORF in domain IV are boxed, and the branch-site A in domain VI is circled. An alternative structure of the unusual insertion in domain D (nt 275-310) is proposed for the $\Delta$ ORF.1 mutant (boxed sequence above the wild-type structure).

that is shared with the E. myxocylindracea intron, although the sequence of the insertion has diverged considerably. Chs.psbA1 is also inserted at the same location in the $p s b A$ gene as the euglenoid intron. Finally, both of these introns are atypical in that they end with CC instead of AY (Bonen and Vogel 2001).

The large ORF (600 amino acids) in domain IV of Chs.psbA1 is preceded by a putative Shine-Dalgarno sequence (AGUAGGU), and contains reverse transcriptase (RT, including subregions 0-7), maturase (X), DNA-binding (D), and endonuclease (HNH) domains (Fig. 3A). Phylogenetic analysis of the ORF (Fig. 3B) places it in subgroup IIB2 or the chloroplast-like class 2 clade of Toor et al.
(2001). The highest sequence identity (52\%) was with the ORF of the E. myxocylindracea intron, and the next highest was with the Calothrix and Nostoc1 ORFs (46\%); the lowest sequence identity was with the Lactococcus lactis intron ORF (25\%). The fact that both the ORF and core structure of Chs.psbAl place it in the same subgroup suggests that the ORF and intron core have coevolved.

\section{Self-splicing of Chs.psbA1 in vitro}

In the initial test for self-splicing of Chs.psbA1, a pre-RNA containing the full-length intron (similar to wild-type pre-RNA in Fig. 4A but with a longer 3' exon) was used. The pre-RNA was incubated under conditions previously shown to promote self-splicing of other group II introns and analyzed by denaturing gel electrophoresis. An autoradiograph, similar to that shown in Figure $4 \mathrm{~B}$ (lanes 1,2), indicated the presence of slowly migrating lariat as well as spliced-exon RNAs. When these reactions were subjected to reverse transcription and PCR (RT-PCR) with flanking exon primers, a product of the size expected for spliced exons was obtained (data not shown, but see below).

Because only a very small fraction of the 2.9-kb pre-RNA spliced, steps were taken to improve the splicing efficiency. One was to shorten the $3^{\prime}$ exon to $92 \mathrm{nt}$ by using primer 177 instead of 100 for PCR (as in the wild-type pre-RNA in Fig. 4B); however, that resulted in only a small increase in splicing efficiency. Hence, we deleted 1575 bp of the ORF (amino acids 43-567), creating the $\triangle$ ORF template (Fig. 4A). We also cloned the $\triangle$ ORF PCR product, generating the $\triangle$ ORF.1 plasmid DNA (Fig. 4A). Sequencing of the $\triangle$ ORF.1 insert, however, revealed four substitutions compared to the original full-length (wild-type intron) PCR product: one change $\left(\mathrm{C}^{304} \rightarrow \mathrm{U}^{304}\right)$ was in the domain-I insertion (see the alternative, boxed region in Fig. 2), and the other three $\left(\mathrm{U}^{756} \rightarrow \mathrm{C}^{756}\right.$, $\mathrm{G}^{844} \rightarrow \mathrm{A}^{844}$, and $\mathrm{C}^{874} \rightarrow \mathrm{U}^{874}$ ) were in the remnant of the ORF in $\triangle$ ORF.1. These substitutions were probably introduced during sequential PCR. As Figure $4 \mathrm{~B}$ shows, the $\triangle \mathrm{ORF}$ and $\triangle \mathrm{ORF} .1$ pre-RNAs spliced more efficiently than wild type. It was also easier to visualize the smaller lariat RNAs with these constructs. The multiple bands of the 


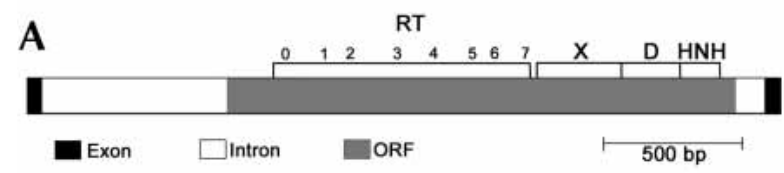

B

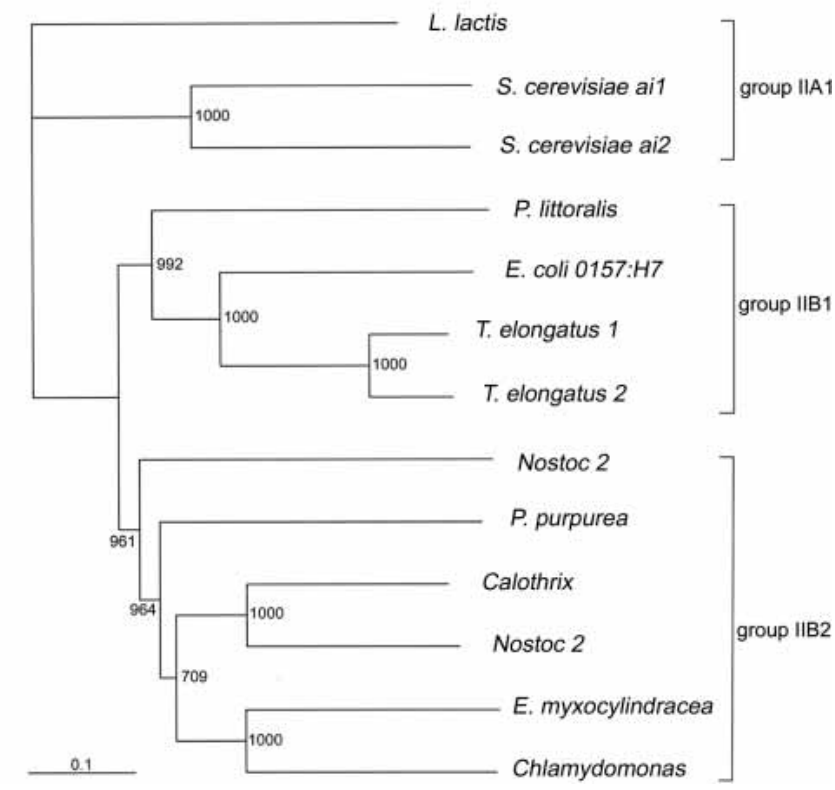

FIGURE 3. Domain structure and phylogenetic analysis of the Chlamydomonas sp. (CCMP-1619) Chs.psbA1 intron ORF. (A) Diagram of the intron and ORF subdomains. (RT) reverse transcriptase; (X) maturase; (D) DNA-binding; (HNH) endonuclease. (B) Phylogenetic analysis of the ORF. The neighbor-joining tree was generated with clustal X using amino acid sequences of selected group II intron ORFs. The scale bar is 0.1 substitutions per site. The bootstrap values are out of 1000 possible trees, and the L. lactis protein was the outgroup. The ORFs contained all of the domains indicated in A. The ORF sequences and their accession numbers are: Calothrix, Calothrix sp. (X71404.1:1034-2788); Chlamydomonas, Chlamydomonas sp. CCMP-1619 chloroplast psbA intron; E. coli, Escherichia coli 0157:H7 (AF074613.1:58,849-60,573); E. myxocylindracea, Euglena myxocylindracea chloroplast psbA intron (AY290861); L. lactis, LtrA of Lactococcus lactis (AAB06503.1); Nostoc 1, Nostoc sp. PCC 7120 (AP003604.1:45,989-47,791); Nostoc 2, Nostoc sp. PCC 7120 (AP003599.1:30,840-32,459); P. purpurea, Porphyra purpurea mitochondrial rRNA intron 1 (AF114794.1:2909-4543); P. littoralis, Pylaiella littoralis mitochondrial rRNA intron 2 (AJ277126.1:4664-6370); S. cerevisiae ail, Saccharomyces cerevisiae mitochondrial COXI intron ai1 (NP_009310.1); S. cerevisiae ai2, Saccharomyces cerevisiae mitochondrial COXI intron ai2 (NP_009309.1); T. elongatus 1, Thermosynechococcus elongatus BP-1 (AP005369.1:28791-30,485); T. elongatus 2, Thermosynechococcus elongatus BP-1 (AP005371.1:25,718-27,406).

spliced-exons product are likely due to heterogeneity at the termini.

The optimum concentrations of $\mathrm{Mg}^{2+}$ and $\mathrm{NH}_{4}{ }^{+}$ions, which are typically used in group II self-splicing experiments, were examined with Chs.psbAl. Splicing was detected at $12-13 \mathrm{mM} \mathrm{MgCl} 2\left(500 \mathrm{mM} \mathrm{NH}_{4} \mathrm{Cl}\right)$, and there was a broad optimum of $25-100 \mathrm{mM}$. Self-splicing of Chs.psbAl was undetectable in the absence of $\mathrm{NH}_{4}{ }^{+}$, and was optimal at 1-1.5 $\mathrm{M} \mathrm{NH}_{4} \mathrm{Cl}$. Spermidine did not stimulate Chs.psbA1 self-splicing.

The effect of a denaturation-renaturation cycle was also examined. Renatured RNAs spliced more efficiently than RNAs purified from denaturing gels without renaturation, but less efficiently than RNAs taken directly from transcription reactions (not shown). Even extracting the transcription reactions with chloroform reduced the splicing efficiency of the various RNAs, as shown by the $\triangle \mathrm{ORF}$ and $\Delta$ ORF.1 pre-RNAs in Figure 4B. Splicing of extracted wild-
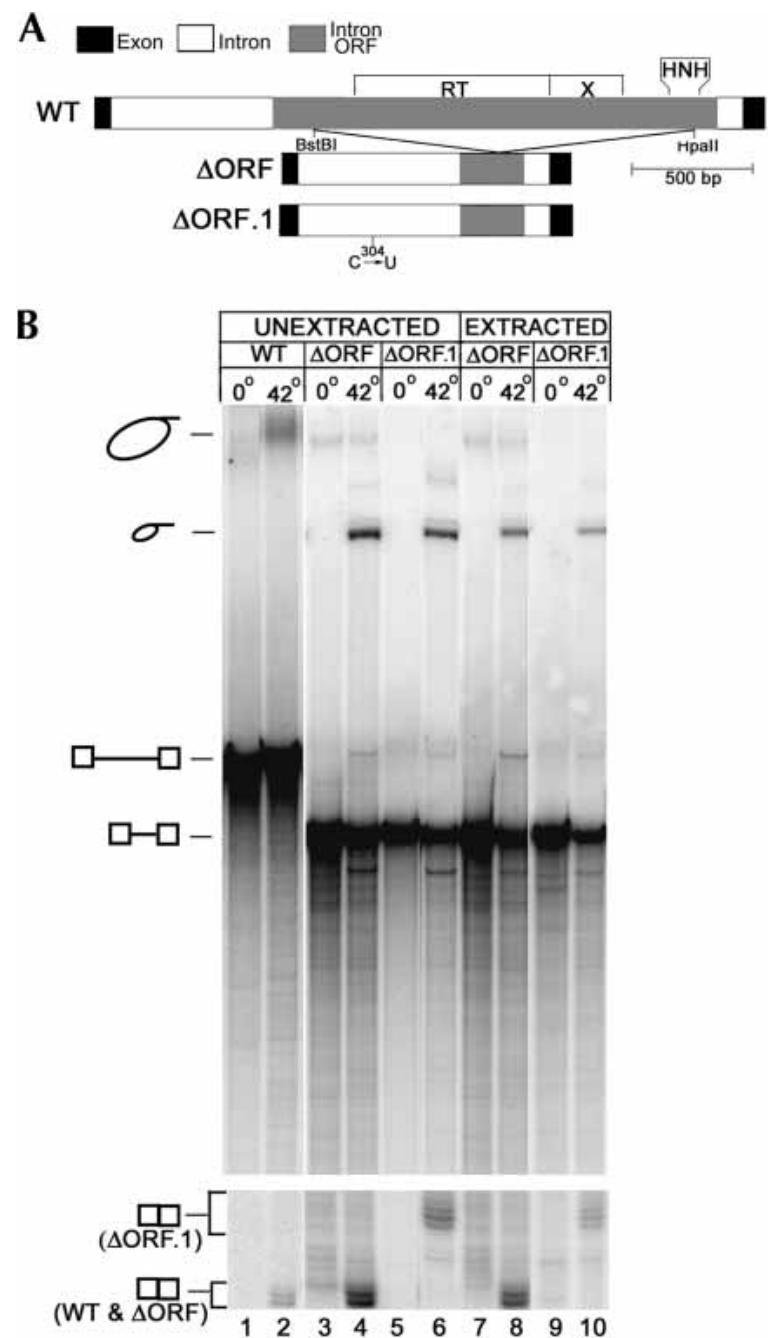

FIGURE 4. In vitro self-splicing of ${ }^{32} \mathrm{P}$-labeled Chs.psbA1 pre-RNAs. (A) Maps of the pre-RNAs. Wild-type and $\triangle \mathrm{ORF}$ pre-RNAs have the same $5^{\prime}$ (67 nt) and $3^{\prime}$ (92 nt) exons, whereas the $5^{\prime}$ and $3^{\prime}$ exons of $\Delta$ ORF.1 have an additional $5 \mathrm{nt}$. The wild-type intron is $2572 \mathrm{nt}$, and $997 \mathrm{nt}$ in the $\triangle$ ORF and $\Delta$ ORF.1 pre-RNAs. The nucleotide substitution in the $\triangle$ ORF. 1 core is indicated. See Figure 3 for explanation of ORF domains. (B) Gel analysis of splicing reactions with ${ }^{32} \mathrm{P}$-labeled pre-RNAs. The reactions were incubated at $0^{\circ} \mathrm{C}$ or $42^{\circ} \mathrm{C}$ for $90 \mathrm{~min}$ and then analyzed on a denaturing polyacrylamide gel. "Unextracted" RNAs were taken from transcription reactions and used for splicing without treatment; "extracted" RNAs were extracted with chloroform and ethanol precipitated before splicing. The location of excised lariat, precursor, and spliced-exon RNAs are indicated to the left. 
type pre-RNA was not included in Figure 4B, because it was so inefficient. These results suggest that some folding of the pre-RNA occurs in the transcription reaction that improves subsequent self-splicing. The folding is presumably incomplete, however, because there was no evidence of splicing during transcription. By incorporating all of the above findings, plus the temperature optimization (see below), 20\% of the $\Delta$ ORF and $\sim 30 \%$ of the $\Delta$ ORF.1 pre-RNAs selfspliced in vitro after $180 \mathrm{~min}$.

Reverse transcription coupled with PCR (RT-PCR) was used to judge the accuracy of self-splicing and to determine the branch site. As shown in Figure 5A, the RT-PCR product corresponding to spliced-exons RNA (E1-E2) depended on incubation of the splicing reaction at elevated temperature, as expected, and was also reverse transcriptase dependent (not shown). Sequencing of this product from wildtype as well as $\triangle$ ORF and $\triangle$ ORF.1 splicing reactions confirmed that the exons had been spliced correctly.

A

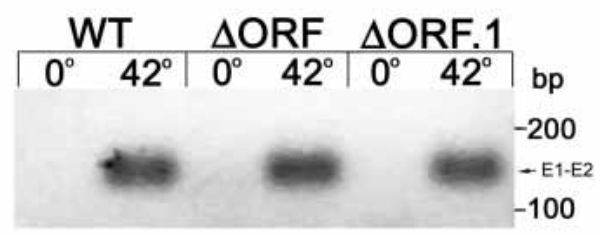

B

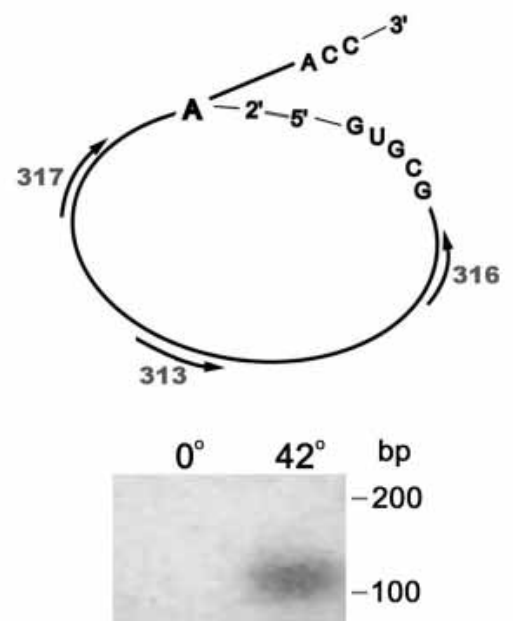

FIGURE 5. RT-PCR analysis of Chs.psbA1 self-splicing and branching. (A) RT-PCR of spliced-exon RNA. RT-PCR was performed with flanking exon primers on splicing reactions incubated at the indicated temperatures $(2 \mathrm{~h})$. The portion of the ethidium-agarose gel containing the 148-bp product (E1-E2) that was eluted and sequenced is shown, and the locations of size markers are indicated. The image was captured with a digital camera and then inverted. (B) RT-PCR analysis of the branch site. (Above) A diagram of the excised intron lariat showing the location of the DNA primers used for the RT-PCR. Reverse transcription (RT) was with primer 313 , and then nested PCR was performed with primers 316 and 317. (Below) The wild-type preRNA was incubated for self-splicing at the indicated temperatures for $2 \mathrm{~h}$, and then RT-PCR was performed. The ethidium bromide-agarose gel of the RT-PCR product (109 bp) that was eluted and sequenced is shown and the locations of size markers are indicated. The image was captured with a digital camera and then inverted.

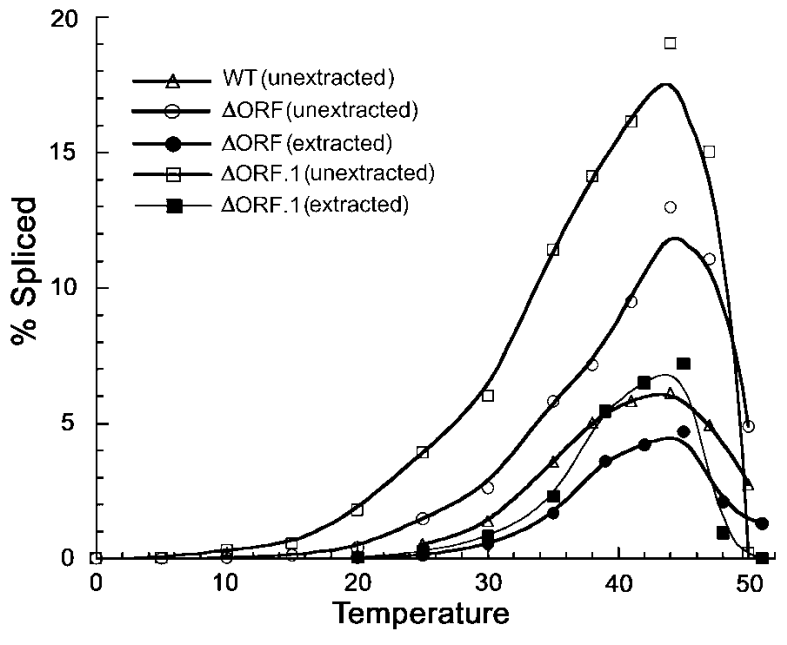

FIGURE 6. Self-splicing of Chs.psbA1 pre-RNAs as a function of temperature. The splicing reactions were performed with ${ }^{32} \mathrm{P}$-labeled preRNAs incubated for $90 \mathrm{~min}$ at the indicated temperatures. The RNAs were separated on denaturing polyacrylamide gels and quantified with a phosphorimager. The fraction (in percent) of pre-RNA that spliced was determined from the fraction of intron (in pre-RNA) that was converted to lariat. As indicated, both unextracted and extracted preRNAs (see Fig. 4) were used.

A nested RT-PCR assay was used to map the branch site in the wild-type intron lariat as described by Vogel et al. (1997). This assay depends on the ability of reverse transcriptase to read through a $2^{\prime}-5^{\prime}$ linkage in the intron lariat at the branch site (diagram in Fig. 5B). In the PCR step, a nested downstream oligonucleotide (primer 316 in Fig. 5B) and an upstream primer (317) are used. A single product was obtained with this assay on wild-type pre-RNA that had been spliced at $42^{\circ} \mathrm{C}$, but no product was obtained with pre-RNA incubated for splicing at $0^{\circ} \mathrm{C}$ (Fig. 5B, lower panel). The sequence of this product (on the sense strand) at the junction of the $3^{\prime}$ and $5^{\prime}$ regions of the intron was $3^{\prime}$-GCGTGTGCTGG-5', where the underlined nucleotide is the branch site. This corresponds to the bulge $\mathrm{A}^{2565}$ in domain VI, similar to other group II introns. It should be noted that with this method, the reverse transcriptase inserts an $\mathrm{A}$ instead of a $\mathrm{T}$ when it encounters the branched A (Vogel et al. 1997).

The temperature optimum for self-splicing was tested with all three unextracted pre-RNAs, as well as extracted forms of $\triangle \mathrm{ORF}$ and $\triangle \mathrm{ORF} .1$. Figure 6 shows the fraction of each RNA that spliced in $90 \mathrm{~min}$, based on lariat accumulation. The lariat was used because it was relatively easy to quantify, and its accumulation correlated well with accumulation of spliced-exons RNA. The optimum splicing temperature for the different pre-RNAs was close to $44^{\circ} \mathrm{C}$. Figure 6 also shows that there is a broad shoulder on the low side of the peak, and, moreover, that splicing of the more active pre-RNAs was observed below $20^{\circ} \mathrm{C}$. At temperatures above the optimum, self-splicing dropped off quickly; in fact, with the most active pre-RNA ( $\Delta$ ORF.1, 
unextracted), there was almost no splicing at $50^{\circ} \mathrm{C}$. The steep drop in self-splicing at the higher temperature most likely reflects a loss of structure.

To determine rate constants for Chs.psbA1 self-splicing, time-course reactions of the shorter pre-RNAs ( $\triangle \mathrm{ORF}$ and $\Delta$ ORF.1) were performed at $41^{\circ} \mathrm{C}$; a representative analysis for the $\triangle \mathrm{ORF}$ (extracted) RNA is shown in Figure 7A. The reaction was fairly linear at the early time points (10-20 min) and was nearly complete by $100 \mathrm{~min}$ (Fig. 7B). The linearity of the semi-log plot of the decay of active pre-RNA over time (Fig. 7C) suggested that the active fraction was one kinetic component. The $k_{o b s}$ for the initial splicing rate of this pre-RNA was $0.017 \mathrm{~min}^{-1}$. The $k_{o b s}$ for selfsplicing by the $\Delta$ ORF and $\triangle$ ORF.1 pre-RNAs, both unextracted and extracted, was also determined, and found to vary less than twofold, ranging from $0.016 \mathrm{~min}^{-1}$ to 0.020 $\min ^{-1}$; these rates are similar to other self-splicing group II introns (Hebbar et al. 1992; Jarrell et al. 1988; Adamidi et al. 2003).

\section{Splicing of Chs.psbA1 in E. coli}

Because chloroplast genes, including intron-encoded ones (Lee 2003), usually express at some level in E. coli, we decided to see if the Chs.psbA1 intron would splice in E. coli and, if so, if its splicing would be ORF dependent. The recombinant intron plasmids also contained a $\mathrm{T} 7$ promoter upstream of the inserted DNA, which enabled transcription in E. coli strains producing the T7 RNA polymerase. RTPCR with primers flanking the intron was used to assess splicing of Chs.psbA1. As Figure 8 shows, a product of the size expected for spliced-exons RNA (E1-E2) was obtained with the wild-type, but not the $\triangle$ ORF.1 intron; the figure also shows that the E1-E2 product is reverse transcriptase dependent. An RT-PCR product of the size expected for unspliced RNA (pre-RNA) was obtained for both wild-type and ORF.1 introns, verifying that the pre-RNA was transcribed in both clones. Analysis of three other wild-type clones and one other $\triangle$ ORF.1 clone produced the same results (data not shown). Sequencing of the E1-E2 product verified that it was from correctly spliced RNA. We also sequenced the RT-PCR products migrating at $\sim 0.6 \mathrm{~kb}$ and just faster than the E1-E2 product in Figure 8, which revealed that these were due to spurious priming.

Two other Chs.psbA1 intron mutants were examined for splicing in E. coli using the same assay; one has a frame-shift mutation after amino acid 10 of the ORF (FS), and the other has two point (i.e., missense) mutations (PM), one in the maturase domain $\left(\mathrm{G}^{456} \rightarrow \mathrm{D}^{456}\right)$, and the other in the reverse transcriptase domain $\left(\mathrm{L}^{333} \rightarrow \mathrm{P}^{333}\right)$. Figure 8 shows that there was little or no splicing of Chs.psbA1 with these two mutants. Subjecting the products of the RT-PCR reactions in Figure 8 to another round of PCR with the same or a nested downstream primer still did not produce any spliced-exons product with the $\Delta$ ORF.1 and missense (PM) mutants, but a small amount was visible with the frame-shift mutant (not shown). The latter result may be due to some translation from an in-frame GUG codon, which is $96 \mathrm{nt}$ from the normal start codon and preceded by a possible Shine-Dalgarno sequence (AAGGA), or from the first internal methionine $\left(\mathrm{M}^{123}\right)$ of the ORF, which is also preceded by a possible Shine-Dalgarno sequence (GAAG). In summary, these results provide genetic evidence that the Chs.psbA1 ORF encodes a maturase.

\section{Splicing of Chs.psbA1 in Chlamydomonas CCMP-1619}

The splicing efficiency of Chs.psbA1 in CCMP-1619 cells growing photoautotrophically at $8^{\circ} \mathrm{C}$ (Morgan et al. 1998) was assessed by Northern blot hybridization (Fig. 9). The exon-specific probe gave a very strong signal with a $1.1-\mathrm{kb}$ RNA that comigrated with $C$. reinhardtii psbA mRNA (lane 1). The intron-specific probe detected RNAs of 2.6, 3.2, 


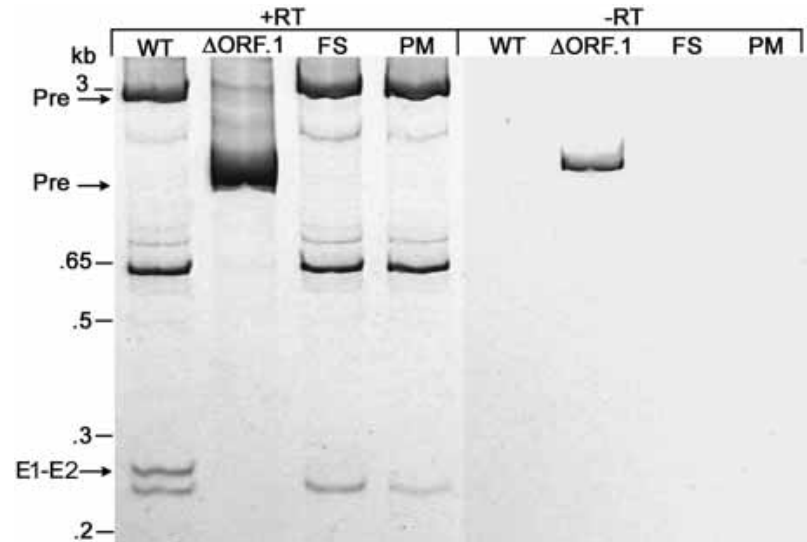

FIGURE 8. ORF-dependent splicing of the Chs.psbAl intron in E. coli. Expression of the intron constructs in E. coli was induced with IPTG, and RNA was extracted and analyzed by RT-PCR with primers flanking the Chs.psbA1 intron. The reverse transcription step was performed with a T3 promoter primer that anneals just downstream from the $p s b A$ exon 2 sequence, and then PCR was performed with the same primer plus one in $p s b A$ exon 1 . The RT-PCR reactions were either complete $(+\mathrm{RT})$ or lacked the reverse transcriptase $(-\mathrm{RT})$. The E. coli clones contained the following forms of the Chs.psbAl intron: WT, wild-type; $\triangle$ ORF.1, ORF-deleted; FS, frame-shift mutation after amino acid 10 of the ORF; and PM, two missense (point) mutations, one in the RT domain and one in the maturase (X) domain. The samples were analyzed by electrophoresis in a $6 \%$ polyacrylamide gel (native), which was stained with SYBR Green I and photographed with short-wave UV epi-illumination and a digital camera; the image shown was inverted. The positions and sizes of selected DNA size markers and the identification of RT-PCR products from the unspliced (Pre) and spliced-exon (E1-E2) RNAs are indicated to the left.

3.9, and $4.3 \mathrm{~kb}$. The $2.6-\mathrm{kb}$ RNA could be the free intron, because lariats migrate approximately according to their size in agarose gels (Domdey et al. 1984). The 3.9- and 4.3-kb RNAs are large enough to be unspliced precursors; however, only the 4.3-kb RNA clearly hybridized with the exon probe, suggesting that it is a bona fide pre-mRNA. The fact that the 4.3-kb RNA is longer than the minimum $3.7 \mathrm{~kb}$ required for unspliced pre-RNA may indicate that the $p s b A$ gene contains another smaller intron or that there is a small gene cotranscribed with $p s b A$. Phosphorimager analysis of this and two other blots showed that $>98 \%$ of the hybridization signal with the exon probe came from the mature $p s b A$ mRNA, indicating that the Chs.psbA1 intron is spliced efficiently at $8^{\circ} \mathrm{C}$ in vivo. Figure 9 also shows that there was no increase in the level of pre-RNA $(4.3-\mathrm{kb})$ when the cells were shifted to darkness for $3 \mathrm{~h}$, suggesting that there is no light requirement for Chs.psbA1 splicing, as there is for the $p s b A$ introns in C. reinhardtii (Deshpande et al. 1997). The lack of change in the level of the mature mRNA after $3 \mathrm{~h}$ in the dark was expected, because mature $p s b A$ mRNA is very long-lived (Hwang and Herrin 1994). The increase in the putative free intron RNA $(2.6 \mathrm{~kb})$ in the dark may be due to decreased degradation; a similar result was obtained with free $p s b A$ intron RNAs in C. reinhardtii (Deshpande et al. 1997).

\section{DISCUSSION}

We have identified a group II intron in the chloroplast $p s b A$ gene of a psychrophilic Chlamydomonas sp. that shows selfsplicing activity in vitro. Chs.psbA1 is only the second group II intron from a chloroplast gene shown to be autocatalytic - the first was reported while this article was in preparation (Sheveleva and Hallick 2004), and, remarkably, is closely related to this Chlamydomonas intron, although it is from an unrelated euglenoid. The relative paucity of autocatalytic group II introns from chloroplasts may be because most of the known ones are from vascular plants and euglenoids, which appear to rely mainly on protein-dependent splicing (Jenkins et al. 1997). The Chs.psbA1 intron is also the first cis-spliced group II intron from Chlamydomonas, and it is not closely related to the two trans-spliced group II introns in the psaAl gene (for review, see Herrin et al. 1998).

The proposed secondary structure for Chs.psbA1 places it in subgroup IIB2; however, it has an idiosyncratic insertion in domain ID that can affect splicing. The latter conclusion is based on the fact that the $\Delta$ ORF.1 pre-RNA, which has a nucleotide substitution in the insertion, splices more efficiently than the $\triangle$ ORF pre-RNA, which does not. Comparison of the predicted wild-type and mutant structures in this region suggests that there is a little better stability in the mutant, which, in turn suggests that this unusual insertion may inhibit self-splicing in vitro by forming alternate structures with other parts of the intron.

We obtained genetic evidence that the ORF in Chs.psbA1 has maturase activity. A putative group II intron maturase in the trnK (lysyl tRNA) gene (matK) of angiosperm chloroplasts has been implicated in splicing of its own and other

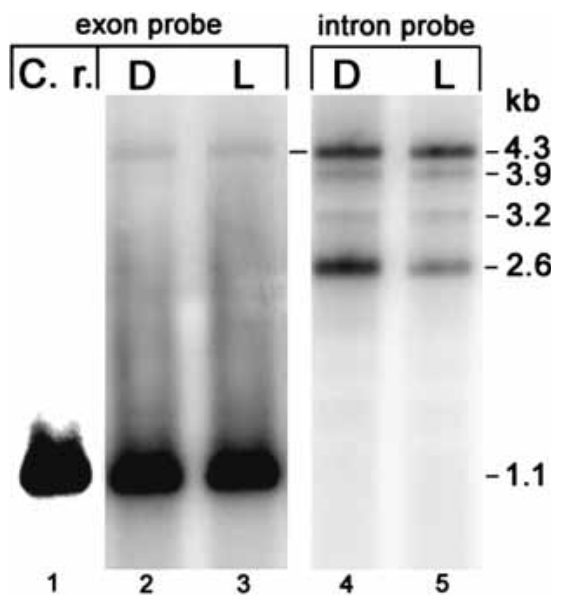

FIGURE 9. Northern blot analysis of $p s b A$ transcripts in Chlamydomonas sp. CCMP-1619. CCMP-1619 was grown in continuous light at $8^{\circ} \mathrm{C}$ (lanes $L$ ), and then some cells were shifted to darkness for $3 \mathrm{~h}$ (lanes $D$ ). RNA was isolated and hybridized with either ${ }^{32} \mathrm{P}$-labeled exon DNA (Exon Probe) or a Chs.psbA1 intron fragment (Intron Probe). RNA from C. reinhardtii (C.r.) was used as a marker for mature $p s b A$ mRNA. C. reinhardtii rRNAs on the methylene bluestained blot were used as size markers. 
group II introns (du Jardin et al. 1994; Liere and Link 1995; Vogel et al. 1997, 1999); however, because only binding of the protein to its intron was reported (Liere and Link 1995), the implication is that it does not promote splicing of the trnK intron by itself. The fact that we observed ORF-dependent splicing of Chs.psbA1 in E. coli bodes well for possibly overproducing this protein for biochemical studies. SDS-PAGE analysis of total soluble protein from the wildtype Chs.psbA1 transformants did not reveal an abundant polypeptide of the size expected for the ORF, suggesting that production of the protein using its own translation signals was rather low (O. Odom and D. Herrin, unpubl. results). This may explain why splicing of wild-type Chs.psbA1 in E. coli was somewhat inefficient.

The only group II intron maturase that has been studied biochemically is from the group IIA intron, Ll.LtrB, of the bacterium $L$. lactis. The intron-ORF protein, LtrA, binds with high affinity to subdomain IVa, which includes the beginning of the LtrA coding region (Wank et al. 1999). Secondary contacts are then made to conserved regions of the intron core, with the effect of promoting tertiary folding of the intron (Matsuura et al. 2001). A predicted fold of domain IV in Chs.psbA1 (Fig. 2) reveals a possible IVa subdomain that also contains the putative Shine-Dalgarno sequence, but it is considerably reduced compared to Ll.LtrB. Moreover, we could not find an analogous structure upstream of the ORFs in the related Calothrix and Nostoc introns, suggesting that group IIB maturases may bind their introns differently than LtrA. In this respect, we also note that the IVa subdomain of the Saccharomyces cerevisiae mitochondrial COXI ai2 group IIA intron seems to play a reduced role in maturase-dependent splicing of this intron in vivo, although it is critical for ai2 homing (Huang et al. 2003).

To our knowledge, the Chs.psbA1 intron is the first ribozyme described from a psychrophile. The ionic requirements for Chs.psbA1 self-splicing are similar to those of other group II introns in requiring fairly high $\mathrm{Mg}^{2+}$ and high $\mathrm{NH}_{4}^{+}$, although the minimal $\mathrm{Mg}^{2+}$ requirement (13 $\mathrm{mM}$ in the absence of a polycation) appears to be lower than for some group II introns (Jarrell et al. 1988; Hebbar et al. 1992; Adamidi et al. 2003). Evidence was also presented for productive, cotranscriptional folding of the preRNA in vitro. The proposed folding is likely only partial, however, because splicing did not occur in the transcription reactions. Cotranscriptional folding is presumably what happens in vivo, and could help prevent the formation of some nonproductive isomers that form during denaturation-renaturation cycles in vitro. Cotranscriptional folding has been shown to improve group I intron self-splicing (Heilmann-Miller and Woodson 2003).

Self-splicing of Chs.psbA1 occurred via a lariat; however, there could also have been a fraction of the pre-RNA that spliced via a hydrolysis mechanism. There is a band in the gels of ${ }^{32} \mathrm{P}$-labeled RNA splicing reactions that might rep- resent excised linear intron (e.g., Fig. 4B). We did not try to quantify this band, but it is clearly weaker than the intron lariat band. The A residue utilized in the lariat pathway is in domain VI, its usual location, although it is somewhat atypical in that it is in an asymmetric internal loop $\left(\mathrm{A}^{2565}\right.$ in Fig. 2). The rates of self-splicing of the $\triangle \mathrm{ORF}$ and $\triangle \mathrm{ORF} .1$ pre-RNAs via the lariat mechanism are in the range of other self-splicing group II introns (Daniels et al. 1996; Adamidi et al. 2003). With the most active preparation ( $\Delta$ ORF.1, unextracted), $25-30 \%$ of the pre-RNA self-spliced. Thus, the extent of Chs.psbA1 self-splicing seems to be somewhat less than the more robust group II introns from mitochondria and prokaryotes (Daniels et al. 1996; Costa et al. 1997; Adamidi et al. 2003). With the full-length Chs.psbAl intron, only $4 \%-5 \%$ of the pre-RNA spliced, suggesting that Chs.psbA1 is an inefficient folder. It is possible that inefficient folding to the active state reflects an adaptation to low temperature. If increased flexibility enhances ribozyme function at low temperature as it does for protein enzymes (Hochachka and Somero 2002), then such flexibility could manifest itself as a reduction in stability of the catalytically active state of the ribozyme. Of course that raises the question of how splicing is made efficient in vivo.

The temperature optimum for Chs.psbAl self-splicing was determined to be $\sim 44^{\circ} \mathrm{C}$ for the different forms of the pre-RNA. This seems to be similar to, or somewhat lower in some cases, than other group II introns (Jarrell et al. 1988; Winkler and Kück 1991; Hebbar et al. 1992; Costa et al. 1997; Adamidi et al. 2003). On the other hand, the poor self-splicing of Chs.psbA1 at $50^{\circ} \mathrm{C}$ suggests that Chs.psbA1 is more thermolabile than other group II introns. It may also be significant that there is a shoulder on the cold side of the temperature peak (Fig. 6), and that self-splicing of Chs.psbA1 was clearly detected at low $\left(<20^{\circ} \mathrm{C}\right)$ temperatures. In contrast, Hebbar et al. (1992) reported that the yeast aI1 intron was essentially devoid of self-splicing activity at $30^{\circ} \mathrm{C}$. It is also interesting to note that self-splicing of the Pylaiella littoralis mitochondrial rRNA intron, Pl.LSU/2, was readily detected at $25^{\circ} \mathrm{C}$ (Costa et al. 1997). Although not shown to be a true psychrophile, to our knowledge, $P$. littoralis is common in northern temperate waters (Voipio 1987; Milchakova 1999). We conclude that this ribozyme shows some evidence of adaptation to low temperature, but the adaptation is not as dramatic as with many protein enzymes (e.g., Loppes et al. 1996; Irwin et al. 2001), which often show great differences in temperature optima between mesophilic and psychrophilic homologs. However, additional ribozymes from psychrophilic organisms need to be examined before general conclusions are drawn.

The analysis of $p s b A$ transcripts in CCMP-1619 indicated that Chs.psbA1 splicing is efficient in these cells at $8^{\circ} \mathrm{C}$. Thus, it seems likely that, in vivo, proteins function to promote splicing of this intron ribozyme at low temperature. As indicated here, the intron-encoded ORF appears to be one such factor, but there could be others (Lambowitz et al. 
1999; Bunse et al. 2001). It also follows, then, that most of the molecular adaptations that enable splicing of this group II intron to be efficient at low temperatures are to be found with these protein factors and their effect on the RNA.

Unlike $p s b A$ splicing in $C$. reinhardtii (which has group I introns), no evidence was obtained for a light requirement for Chs.psbA1 splicing. This result is perhaps not surprising, because the photosynthetic machinery of Chlamydomonas sp. CCMP-1619 is clearly adapted for growth under constant dim light (Morgan-Kiss et al. 2002). Thus, CCMP1619 should not require as tight a control over $p s b A$ expression as does C. reinhardtii.

Another interesting evolutionary question concerns the origin of the Chs.psbA1 intron. The similarity of this intron to several introns from cyanobacteria is intriguing, because chloroplasts are evolutionarily derived from cyanobacteriallike organisms. However, $p s b A$ genes in most photosynthetic organisms, including Calothrix and Nostoc, lack group II introns. It was suggested previously that the Chs.psbA1-related intron from the E. myxocylindracea chloroplast $p s b A$ gene was acquired horizontally from a cyanobacterium (Sheveleva and Hallick 2004). The chloroplast genome of Euglena spp. is believed to be of green algal origin, having been acquired by secondary endosymbiosis. Because Sheveleva and Hallick (2004) found that several other Euglena species tested lack this intron in their $p s b A$ gene and we have also found that the Chs.psbA1 intron is lacking from several other species of Chlamydomonas that were examined (O. Odom, D. Shenkenberg, and D. Herrin, unpubl. results), it seems unlikely that these introns were acquired vertically from a common chloroplast ancestor. We suggest, therefore, that the Chs.psbA1 intron was acquired by an independent horizontal transfer from a cyanobacterium. This suggestion is also supported by the fact that the GC content of the Chs.psbA1 intron (45\%) is much closer to the genes of Nostoc and Calothrix (43\%) than to chloroplast genes of Chlamydomonas spp. (34\%). It is likewise intriguing that Nostoc spp. are found at Lake Bonney, Antarctica (Paerl et al. 2000). In summary, this group II intron (or a close relative) has apparently jumped across the prokaryotic-eukaryotic divide at least twice. It will be interesting to see if it is a mobile intron.

\section{MATERIALS AND METHODS}

\section{Cell culture}

Chlamydomonas sp. CCMP-1619 was obtained from the Provasoli-Guillard Center and C. subcaudata (SAG 12.87) from the Göttingen Collection. The growth medium was soil-water extract (Pringsheim 1946) or Sager-Granick minimal medium (Harris 1989) modified by eliminating $\mathrm{FeCl}_{3}$, reducing $\mathrm{MgSO}_{4} \cdot \mathrm{H}_{2} \mathrm{O}$ threefold, using Hutner's trace metals $(1 \mathrm{~mL} / \mathrm{L})$, and buffering with MES (0.2 g/L; pH 6.8). Filter-sterilized f/2 (Guillard 1975) vitamin solution $(0.5 \mathrm{~mL} / \mathrm{L})$ and ampicillin $(100 \mu \mathrm{g} / \mathrm{mL})$ were added after autoclaving. For RNA analysis, the cells were grown at $8^{\circ} \mathrm{C}$ under continuous illumination $\left(60 \mu \mathrm{moles} / \mathrm{m}^{2} / \mathrm{sec}\right)$ and slow bubbling with $5 \% \mathrm{CO}_{2}$.

\section{Isolation of algal DNA, PCR, and DNA constructs}

Total nucleic acids (TNA) were isolated from liquid cultures as described (Durrenberger et al. 1996), except RNase A was omitted. PCR amplification of $p s b A$ used primers 176 (TTCATTCTCTGA CGGTATGCCTTTAGG) and 100 (TAGGATCCAAGCAGCTAA GAAGAAGTGTAATG), 30 ng TNA, Taq DNA polymerase, and an annealing temperature of $60^{\circ} \mathrm{C}$. The $2.9-\mathrm{kb}$ product was sequenced by primer walking (accession no. AY325305). Amplification of the petA-petD region was performed with primers 330 (GCTGTTTTACCAGATACTGTTTTTG) and 332 (CCATACCTT TAGCTAATTTAGCTT) and an annealing temperature of $45^{\circ} \mathrm{C}$. The 1.9-kb product was sequenced (the CCMP-1619 sequence was deposited in GenBank, accession no. AY332410). The transcription template containing the full-length intron and partial flanking exons (wild-type) was synthesized by PCR of Chlamydomonas sp. CCMP-1619 TNA with primers 310 (TAATACGACTCACTATA GGGATCCCGGGTTCATTCTCTGACGGTATGCCTTTAGG) and either 177 (GTGCATAGCTGAGAATAATGAACCACC) or 100. The ORF-deleted $(\triangle \mathrm{ORF})$ DNA was generated as follows. The 310/177 PCR product was digested with BstBI and StuI, giving fragments of 872,1441 , and $435 \mathrm{bp}$. The 435-bp fragment was digested with HpaII, which yielded fragments of 134 and $301 \mathrm{bp}$, and the 301-bp fragment was ligated to the 872-bp fragment via the complementary 5'-CG overhangs generated by HpaII and BstBI. An aliquot of the ligation mixture was used for PCR with primers 310 and 177 , and the expected $1.2-\mathrm{kb}$ product was sequenced. The $\Delta$ ORF.1 plasmid was generated by cloning the $\triangle$ ORF DNA into pBluescript SK+ after an additional round of PCR with primers 322 (TAGGTACCTTCATTCTCTGACGGTAT GCCTTTAGG) and 323 (TAAAGCTTGTGCATAGCTGAGAAT AATGAACCACC), and digestion with KpnI and HindIII. A $\triangle$ ORF.1 clone was identified and the insert sequenced. The constructs for analyzing Chs.psbA1 splicing in E. coli were obtained by PCR of Chlamydomonas sp. CCMP-1619 TNA with exon primers 322 and 323 and cloning into Bluescript SK+. Sequencing of several clones did not yield one without mutations, so one was created by exchanging NheI-KpnI fragments.

\section{In vitro RNA synthesis and self-splicing}

RNA was synthesized from PCR products or HindIII-digested plasmid DNA (200 ng) with T7 RNA polymerase in $20-\mu \mathrm{L}$ volume. After $1 \mathrm{~h}$ at $37^{\circ} \mathrm{C}$, the reactions were either frozen at $-70^{\circ} \mathrm{C}$ or extracted with chloroform/EDTA and precipitated with ethanol. Standard self-splicing reactions $(5 \mu \mathrm{L})$ contained $\sim 80 \mathrm{ng}$ RNA, 40

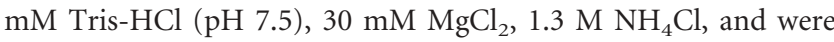
incubated at $42^{\circ} \mathrm{C}$ for $90-180 \mathrm{~min}$; control reactions were incubated at $0^{\circ} \mathrm{C}$. Variations in these conditions are indicated in the text. The reactions were stopped with EDTA and cooled on ice. For gel analysis, RNAs that had not been extracted previously were extracted with chloroform, and all samples were precipitated with ethanol. The ${ }^{32} \mathrm{P}$-labeled RNAs were separated on denaturing $4 \%$ polyacrylamide gels and exposed to X-ray film (BioMax MS) or to a phosphorimager screen that was quantified with ImageQuant (Molecular Dynamics). 
The kinetics of self-splicing of $\Delta \mathrm{ORF}$ and $\Delta \mathrm{ORF} .1$ pre-RNAs were determined at $41^{\circ} \mathrm{C}$ by quantifying gels with a phosphorimager after verifying the integrity of the samples. Semi-log plots of precursor decay were linear for over $100 \mathrm{~min}$, indicative of a single kinetic component. The observed rate constants $\left(k_{o b s}\right)$ were determined from these plots (after correcting for the fraction of active ribozyme, which was determined from a 4-h incubation) or from early time points when the rate of splicing was nearly linear.

\section{Splicing in E. coli}

Plasmids were transformed into the E. coli Rosetta(DE3)pLysS strain (Novagen), and the appropriate clones verified by restriction analysis. Selected transformants were grown in Luria Broth at $37^{\circ} \mathrm{C}$ to an $\mathrm{A}_{650}$ of 0.7 , and then induced at $30^{\circ} \mathrm{C}$ with IPTG (1 $\mathrm{mM}$ ). After $2 \mathrm{~h}$, RNA was isolated as described previously (Herrin and Schmidt 1988), except for resuspending the cells in lysozyme $(0.5 \mathrm{mg} / \mathrm{mL})$ plus $200 \mathrm{U} / \mathrm{mL}$ Superase $\cdot$ In (Ambion), and including two acid-phenol extractions. Most of the residual DNA was removed by degradation with TurboDNAse (Ambion).

\section{RT-PCR}

Reverse transcription was performed with either 2-3 $\mu$ g of E. coli RNA or $\sim 2$ ng of self-spliced RNA in $20 \mu \mathrm{L}$, using Superscript II (Invitrogen) as described by the manufacturer; an aliquot $(1 \mu \mathrm{L})$ was used for PCR (30 cycles). To examine in vitro splicing, primer 177 was used, and for splicing in E. coli, a T3 promoter primer (CGCGCAATTAACCCTCACTAAAGGG) was used for reverse transcription, and then the same primer plus 176 was used for PCR (annealing at $60^{\circ} \mathrm{C}$ ). The products (either 148 or $256 \mathrm{bp}$, respectively) were sequenced using the same primers. To map the intron branch point (Vogel et al. 1997), reverse transcription was performed with primer 313 (GTGCTCTTAGCTGAGCCGTACT TAG), then PCR was carried out with the nested primers 316 (CCACGAAGTTTGACGTTCGATTTCAG) and 317 (GAGCGTA ATGTAGCGAAAGTTACACG). The product (109 bp) was sequenced using the PCR primers. RT-PCR products were analyzed and purified either by ethidum bromide-agarose gel electrophoresis or by polyacrylamide gel electrophoresis and SYBR Green I staining (Molecular Probes).

\section{Algal RNA isolation and Northern blot hybridization}

RNA was isolated from Chlamydomonas and Northern blotted as described (Herrin and Schmidt 1988). The exon-specific probe (343 bp) was obtained by RT-PCR of self-spliced pre-RNA (wildtype) with primers 100 and 176. The Chs.psbAl intron-internal probe $(731 \mathrm{bp})$ was obtained by PCR of TNA with primers 312 (CTAGGCATACCCACTATCAAGGATC) and 313. The probes were labeled by single-sided PCR with $\alpha^{32} \mathrm{P}$-dCTP $(3000 \mathrm{Ci} /$ mmole), and the blots were hybridized and washed at $65^{\circ} \mathrm{C}$ (Church and Gilbert 1984).

\section{ACKNOWLEDGMENTS}

We thank the reviewers for helpful comments, Steve Zimmerly for advice on the proposed secondary structure, and Sameer Islam for drawing the original version of Figure 2. This work was supported by grants from the Department of Energy (DE-FG03-02ER15352) and the Robert A. Welch Foundation (F-1164, to D.L.H.) and an undergraduate research fellowship (to D.L.S.).

The publication costs of this article were defrayed in part by payment of page charges. This article must therefore be hereby marked "advertisement" in accordance with 18 USC section 1734 solely to indicate this fact.

Received February 9, 2004; accepted April 9, 2004.

\section{REFERENCES}

Adamidi, C., Fedorova, O., and Pyle, A.M. 2003. A group II intron inserted into a bacterial heat-shock operon shows autocatalytic activity and unusual thermostability. Biochemistry 42: 3409-3418.

Bonen, L. and Vogel, J. 2001. The ins and outs of group II introns. Trends Genet. 17: 322-331.

Brown, J.W., Haas, E.S., and Pace, N.R. 1993. Characterization of ribonuclease P RNAs from thermophilic bacteria. Nucleic Acids Res. 21: 671-679.

Bunse, A.A., Nickelsen, J., and Kück, U. 2001. Intron-specific RNA binding proteins in the chloroplast of the green alga Chlamydomonas reinhardtii. Biochim. Biophys. Acta 1519: 46-54.

Cannone, J.J., Subramanian, S., Schnare, M.N., Collett, J.R., D'Souza, L.M., Du, Y., Feng, B., Lin, N., Madabusi, L.V., Muller, K.M., et al. 2002. The comparative RNA web (CRW) site: An online database of comparative sequence and structure information for ribosomal, intron, and other RNAs. BioMed Central Bioinform. 3: 2.

Church, G.M. and Gilbert, W. 1984. Genomic sequencing. Proc. Natl. Acad. Sci. 81: 1991-1995.

Costa, M., Fontaine, J.-M., Loiseaux-de Goër, S., and Michel, F. 1997. A group II self-splicing intron from the brown alga Pylaiella littoralis is active at unusually low magnesium concentrations and forms populations of molecules with a uniform conformation. $J$. Mol. Biol. 274: 353-364.

Dai, L. and Zimmerly, S. 2003. ORF-less and reverse-transcriptaseencoding group II introns in archaebacteria, with a pattern of homing into related group II intron ORFs. RNA 9: 14-19.

Daniels, D., Michels, W.J., and Pyle, A.M. 1996. Two competing pathways for self-splicing by group II introns: A quantitative analysis of in vitro reaction rates and products. J. Mol. Biol. 256: 31-49.

Deshpande, N.N., Bao, Y., and Herrin, D.L. 1997. Evidence for light/ redox-regulated splicing of $p s b A$ pre-RNAs in Chlamydomonas chloroplasts. RNA 3: 37-48.

Doetsch, N.A., Thompson, M.D., and Hallick, R.B. 1998. A maturaseencoding group III twintron is conserved in deeply rooted euglenoid species: Are group III introns the chicken or the egg? Mol. Biol. Evol. 15: 76-86.

Domdey, H., Apostol, B., Lin, R.-J., Newman, A., Brody, E., and Abelson, J. 1984. Lariat structures are in vivo intermediates in yeast pre-mRNA splicing. Cell 39: 611-621.

du Jardin, P., Portetelle, D., Harvengt, L., Dumont, M., and Wathelet, B. 1994. Expression of intron-encoded maturase-like polypeptides in potato chloroplasts. Curr. Genet. 25: 158-163.

Durrenberger, F., Thompson, A.J., Herrin, D.L., and Rochaix, J.-D. 1996. Double strand break-induced recombination in chloroplasts of Chlamydomonas reinhardtii. Nucleic Acids Res. 24: 3323-3331.

Ettl, H. 1976. Die Gattung Chlamydomonas Ehrenberg (Chlamydomonas und die nächstverwandten Gattungen II). Nova Hedwigia 49: $1-1122$.

Fang, X.-W., Golden, B.L., Littrell, K., Shelton, V., Thiyagarajan, P., Pan, T., and Sosnick, T.R. 2001. The thermodynamic origin of the stability of a thermophilic ribozyme. Proc. Natl. Acad. Sci. 98: 4355-4360.

Ferat, J.-L. and Michel, F. 1993. Group II self-splicing introns in bacteria. Nature 364: 358-361. 
Fontaine, J.-M., Goux, D., Kloareg, B., and Loiseaux-de Goër, S. 1997. The reverse-transcriptase-like proteins encoded by group II introns in the mitochondrial genome of the brown alga Pylaiella littoralis belong to two different lineages which apparently coevolved with the group II ribosyme lineages. J. Mol. Evol. 44: 33-42.

Guillard, R.R.L. 1975. Culture of phytoplankton for feeding marine invertebrates. In Culture of marine invertebrate animals (eds. W.L. Smith and M.H. Chanley), pp. 26-60. Plenum Press, New York.

Harris, E.H. 1989. The Chlamydomonas sourcebook: A comprehensive guide to biology and laboratory use. Academic Press, San Diego, CA.

Hebbar, S.K., Belcher, S.M., and Perlman, P.S. 1992. A maturaseencoding group IIA intron of yeast self-splices in vitro. Nucleic Acids Res. 20: $1747-1754$.

Heilman-Miller, S.L. and Woodson, S.A. 2003. Effect of transcription on folding of the Tetrahymena ribozyme. RNA 9: 722-733.

Herrin, D.L. and Schmidt, G.W. 1988. Rapid, reversible staining of northern blots prior to hybridization. Biotechniques 6: 196-200.

Herrin, D.L., Kuo, T.-C., and Goldschmidt-Clermont, M. 1998. RNA splicing in the chloroplast. In The molecular biology of chloroplasts and mitochondria in Chlamydomonas (eds. J.-D. Rochaix et al.), pp. 183-195. Kluwer Academic Publishers, Dordrecht, The Netherlands.

Hochachka, P.W. and Somero, G.N. 2002. Biochemical adaptation: Mechanism and process in physiological evolution. Oxford University Press, New York.

Hoham, R.W. and Duval, B. 2001. Microbial ecology of snow and freshwater ice with emphasis on snow algae. In Snow ecology: An interdisciplinary examination of snow-covered ecosystems (eds. H.G. Jones et al.), pp. 168-228. Cambridge University Press, Cambridge, UK.

Huang, H.-R., Chao, M.Y., Armstrong, B., Wang, Y., Lambowitz, A.M., and Perlman, P.S. 2003. The DIVa maturase binding site in the yeast group II intron aI2 is essential for intron homing but not for in vivo splicing. Mol. Cell. Biol. 23: 8809-8819.

Hwang, S. and Herrin, D.L. 1994. Circadian regulation of the gene transcription in Chlamydomonas reinhardtii. Plant Mol. Biol. 26: 557-569.

Irwin, J.A., Gudmunsson, H.M., Martiensson, V.T., Hreggvidsson, G.O., Lanzetti, A.J., Alfredsson, G.A., and Engel, P.C. 2001. Characterization of alanine and malate dehyrodgenases from a marine psychrophile strain PA-43. Extremophiles 5: 199-211.

Jarrell, K.A., Peebles, C.L., Dietrich, R.C., Romiti, S.L., and Perlman, P.S. 1988. Group II intron self-splicing: Alternative reaction conditions yield novel products. J. Biol. Chem. 263: 3432-3439.

Jenkins, B.D., Kulhanek, D.J., and Barkan, A. 1997. Nuclear mutations that block group II RNA splicing in maize chloroplasts reveal several intron classes with distinct requirements for splicing factors. Plant Cell 9: 283-296.

Kaneko, T., Nakamura, Y., Wolk, C.P., Kuritz, T., Sasamoto, S., Watanabe, A., Iriguchi, M., Ishikawa, A., Kawashima, K., Kimura, T., et al. 2001. Complete genomic sequence of the filamentous nitrogen-fixing cyanobacterium Anabaena sp. strain PCC 7120. DNA Res. 8: 205-213.

Lambowitz, A.M., Caprara, M.G., Zimmerly, S., and Perlman, P.S. 1999. Group I and group II ribozymes as RNPs: Clues to the past and guides to the future. In The RNA world, 2nd ed. (eds. R.F. Gesteland et al.), pp. 451-485. Cold Spring Harbor Laboratory Press, Cold Spring Harbor, NY.

Lee, J. 2003. "Mutagenesis and suppression of a light-regulated $p s b A$ intron in Chlamydomonas reinhardtii." Ph.D. thesis, University of Texas at Austin.

Liere, K. and Link, G. 1995. RNA-binding activity of the matK protein encoded by the chloroplast trnK intron from mustard (Sinapis alba
L.). Nucleic Acids Res. 23: 917-921.

Loppes, R., Devos, N., Willem, S., Barthélemy, P., and Matagne, R.F. 1996. Effect of temperature on two enzymes from a psychrophilic Chloromonas (Chlorophyta). J. Phycol. 32: 276-278.

Matsuura, M., Noah, J.W., and Lambowitz, A.M. 2001. Mechanism of maturase-promoted group II intron splicing. EMBO J. 20: 72597270.

Michel, F. and Ferat, J.-L. 1995. Structure and activities of group II introns. Annu. Rev. Biochem. 64: 435-461.

Michel, F., Umesono, K., and Ozeki, H. 1989. Comparative and functional anatomy of group II catalytic introns-A review. Gene 82: 530

Milchakova, N. 1999. On the status of seagrass communities in the Black Sea. Aquatic Bot. 65: 21-32.

Morgan, R.M., Ivanov, A.G., Priscu, J.C., Maxwell, D.P., and Huner, N.P.A. 1998. Structure and composition of the photochemical apparatus of the Antarctic green alga, Chlamydomonas subcaudata. Photosyn. Res. 56: 303-314.

Morgan-Kiss, R.M., Ivanov, A.G., and Huner, N.P.A. 2002. The Antarctic psychrophile, Chlamydomonas subcaudata, is deficient in state I-state II transitions. Planta 214: 435-445.

Neale, P.J. and Priscu, J.C. 1995. The photosynthetic apparatus of phytoplankton from a perenially ice-covered Antarctic lake: Acclimation to an extreme shade environment. Plant Cell Physiol. 36: 253-263.

Nesbo, C.L. and Doolittle, W.F. 2003. Active self-splicing group I introns in $23 \mathrm{~S}$ rRNA genes of hyperthermophilic bacteria, derived from introns in eukaryotic organelles. Proc. Natl. Acad. Sci. 100: 10806-10811.

Paerl, H.W., Pinckney, J.L., and Steppe, T.F. 2000. Cyanobacterialbacterial mat consortia: Examining the functioning unit of microbial survival and growth in extreme environments. Environ. Microbiol. 2: 11-26.

Podar, M., Chu, V.T., Pyle, A.M., and Perlman, P.S. 1998. Group II intron splicing in vivo by first-step hydrolysis. Nature 391: 915918.

Pringsheim, E.G. 1946. The biphasic or soil-water culture method for growing algae and flagellata. J. Ecol. 33: 193-204.

Sheveleva, E.V. and Hallick, R.B. 2004. Recent horizontal intron transfer to a chloroplast genome. Nucleic Acids Res. 32: 803-810.

Thomas, D.N. and Dieckmann, G.S. 2002. Antarctic sea ice-A habitat for extremophiles. Science 295: 641-644.

Toor, N., Hausner, G., and Zimmerly, S. 2001. Coevolution of group II intron RNA structures and their intron-encoded reverse-transcriptases. RNA 7: 1142-1152.

Vogel, J. and Börner, T. 2002. Lariat formation and a hydrolytic pathway in plant chloroplast group II intron splicing. $E M B O ~ J .21$ : 3794-3803.

Vogel, J., Hess, W.R., and Börner, T. 1997. Precise branch point mapping and quantification of splicing intermediates. Nucleic Acids Res. 25: 2030-2031.

Vogel, J., Börner, T., and Hess, W.R. 1999. Comparative analysis of splicing of the complete set of chloroplast group II introns in three higher plant mutants. Nucleic Acids Res. 27: 3866-3874.

Voipio, A. 1987. The Baltic Sea. In Conservation of marine benthic biocenoses in the North Sea and the Baltic (ed. R. Mitchell). Elsevier, Amsterdam.

Wank, H., SanFilippo, J., Singh, R.N., Matsuura, M., and Lambowitz, A.M. 1999. A reverse transcriptase/maturase promotes splicing by binding at its own coding segment in a group II intron RNA. Mol. Cell 4: 239-250.

Winkler, M. and Kück, U. 1991. The group IIB intron from the green alga Scenedesmus obliquus mitochondrion: Molecular characterization of the in vitro splicing products. Curr. Genet. 20: 495-502. 

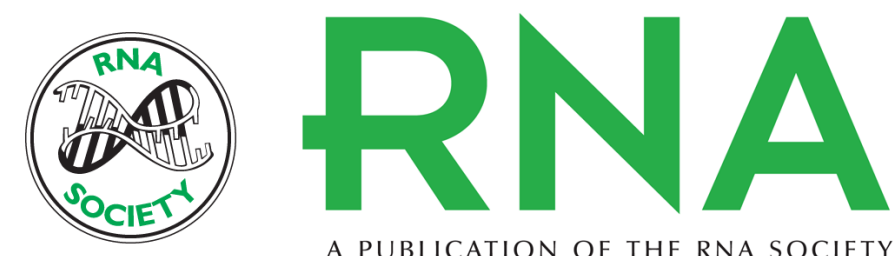

A PUBLICATION OF THE RNA SOCIETY

\section{A horizontally acquired group II intron in the chloroplast $p s b A$ gene of a psychrophilic Chlamydomonas: In vitro self-splicing and genetic evidence for maturase activity}

OBED W. ODOM, DAVID L. SHENKENBERG, JOSHUA A. GARCIA, et al.

RNA 2004 10: 1097-1107

References This article cites 48 articles, 13 of which can be accessed free at:

http://rnajournal.cshlp.org/content/10/7/1097.full.html\#ref-list-1

License

Email Alerting Receive free email alerts when new articles cite this article - sign up in the box at the top Service right corner of the article or click here.

To subscribe to RNA go to:

http://rnajournal.cshlp.org/subscriptions 